\title{
The Importance of Implementing Culturally Responsive Teaching on ASEAN Countries
}

\author{
Sri Trisnawati*, Karin Selma Al-Kautsar, Hidayatul Hamdiah, Sri Tirsna Dewi \\ Universiti Kebangsaan Malaysia, Malaysia
}

@wsritrisna@gmail.com*

\section{Abstract}

A class with various need and kind of students has been widely issued among teachers especially in ASEAN countries. Several studies had been

ARTICLE INFO

Article history:

Received

October 6, 2020

Revised

October 13, 2020

Accepted

October 29, 2020 this article was conducted as the effort to find the solution regarding this issue. This study focuses on Culturally Responsive Teaching in ASEAN countries through examining the previews studies regarding Culturally Responsive Teaching by using PRISMA protocol to collect articles that relevant to this study. The result found that based on 10 articles CRT has found two key points on this matter. Those are misconception of CRT and CRT as the bridge between teacher and student to overcome high-power distance.

Keywords: Culturally Responsive Teaching, High-power distance, ASEAN

How to cite
$\begin{aligned} & \text { Trisnawati, S., Al-Kautsar, K., Hamdiah, H., \& Dewi, S., (2020). An Examination } \\ & \text { of Depressive Symptoms in Adolescents: The Relationship of Personality } \\ & \text { Traits and Perceived Social Support. Attractive Journal, 1(1).p. 1-12 }\end{aligned}$
This is an open access article under the CC BY SA license
https://creativecommons.org/licenses/by-sa/4.0/
CV. Creative Tugu Pena

\section{INTRODUCTION}

A class is not only about a teacher teaching student or the students sitting behind the desk while listening to a teacher. Nevertheless, a class is beyond of that common conception, it is more about complexities and challenges encountered in it. Those complexities and challenges are the students themselves as individuals who come from different background, characteristics, social skill, cognitive abilities, cultural background and habits they hold (Suhono, 2019). Wang, et al, 2019; Porto, M. 2019). Due to the teacher failure to recognize the culture and value the students' adhered and in which class the teacher teaches, it becomes a challenge for the teachers when they want to transform the knowledge to the students but they fail to interpret and comprehend the knowledge conveyed (Heto, et al., 2020; Bonner, P. J. et al., 2018; Latrous, W. O., \& Khadraoui, M. 2020). Therefore, Culturally Responsive Teaching (CRT) exists to answer this issue. However, common misconception' of CRT definition and meaning are frequently occurred on its development (Khadir Rajagopal, 2011; Donna M. et al., 2011), in which it is defined limitedly by the teachers in race, culture and ethnic difference focusing only in 'culturally' meaning (Gay, G, 2018). This caused the teachers to implement inconstant method that waste their time when teaching. Whereas the implementation of CRT is about how the teachers apply an acceptable learning method by the students in a particular classroom.

This also applied to the concept of 'culture' in a class consisting of various individuals. Therefore, Culturally Responsive Teaching exists to be a medium for students and teachers. Culturally Responsive Teaching was initially introduced by Marva Collins, founder of Westside Preparatory School in Chicago in 1992 (Taylor \& Sobel, 2011). Collins created an image metaphor from education through his poetry about how the school has 
given less attention or appreciation to students of various colors. The color here is the membership of the students themselves in terms of race, ethnicity, religion, language, customs and so on. However, the American focus on the division of student culture has been around since 1980 through a program called AVID (The Advancement Via Individual Determination) project at Sandiego Public School (Taylor \& Sobel, 2011). Since then, the concept of Culturally Responsive Teaching continued to develop, especially in America until 2000. Ganeva Gay, a professor at Washington University, developed the idea of Culturally Responsive Teaching and wrote a book called Culturally Responsive Teaching: Theory, Research, and Practice, which becomes one of the primary references to the theory rather than Culturally Responsive Teaching.

According to the above description, the definition of Culturally Responsive Teaching is not just about creating a multicultural classroom with cultural segregation (in the sense of ethnicity and race). But the scope of Culturally Responsive Teaching is broader than that, where CRT invites teachers and classes to create learning environments that bring out the potential of students and the learning styles that teachers and students receive. Where teachers and students have no barriers to transferring such knowledge, values, and norms or custom, when equality, mutual respect, openness, and respect for one another are intertwined, then education aim at humankind will be fully realized.

Besides, Culturally Responsive Teaching (CRT) studies are commonly committed and developed in Western countries (Pei-I. Chou, et al., 2018; Khalifa, M. A., 2016; Parlindungan, et al., 2018). ASEAN countries consisting of ten countries possess multicultural countries for instance Malaysia and Singapore, in which three big ethnicities; Malay, China and India live in it. Additionally, Indonesia is a multicultural country with traditional language, religion and ethnic in which more than a hundred ethnics live and traditional languages spoken in it (Kusumaningputri, \& Widodo, 2018; Albantani, A. M., \& Madkur, A. 2018). Moreover, Philipine with its religion diversity and ethnic (Chee Yen Raymond, Loh, Teck Choon Teo, 2017). Based on a study conducted by Chee Yen R, et al. (2017) to nine Asian countries including six ASEAN countries (Indonesia, Philippine, Malaysia, Singapore, Thailand and Vietnam) and three East Asia countries (China, Hongkong, and South Korea) showed that power distance between teachers and students in teaching and learning is in the high level. This causes the teacher-centered teaching process in which the teachers insist their culture and value to be accepted without willing to share and considering the whole students' condition (Ganeva Gay, 2012). Those issues lead this article to focus on CRT in ASEAN countries through examining the previews studies regarding CRT by using PRISMA protocol to collect articles that relevant to this study.

\section{METHOD}

The methodology is a systematic review using the PRISMA Protocol as an instrument to collect data in the form of past articles/studies on Culturally Responsive Teaching. The PRISMA protocol has been widely used in the process of selecting relevant articles (Bity Salwana Alias, Zaida Nor Zainudin, Nurfaradilla Mohamad Nasri, 2018) There are four steps identified in the PRISMA protocol, those are identification, screening, eligibility, and included (Bity Salwana Alias, Zaida Nor Zainudin, Nurfaradilla Mohamad Nasri, 2018). In the early stages, identification, the article search process is using Google Scholar, UKM E-Journal (Ebscohost and Scopus), and online library Z-library Asia. To identify articles or journals, the keywords used as follows: Culturally Responsive Teaching / Pedagogy, The Implementation of Culturally Responsive Teaching, Diversity of Asian Students, and Multicultural Classroom. In addition, in the identification process, there are several criteria used to obtain data from (i) articles published in 2014-2019 in the form of a journal, proceeding, thesis and reports, (ii) using references from articles obtained to find relevant research, (iii) the article was written in Malay, Indonesian, and English. 
There are 73 articles obtained from all three search engines. Furthermore, at the screening stage, a review of the content and abstracts of the articles was conducted to acquire relevant articles for data analysis and analysis in this study after performing the screening and eligibility phase (s) subject to the purpose of this study.

The framework of the Prism Protocol process formulated in the loop diagram based on prism-statement.org is as follows:

Figure 1: Protocol of Prisma model adapted from prisma-statement.org

\section{Identification}

Number of records identified through database searching

(Google Scholars, UKM E-Journal, Zlibrary.Asia)

n: 73

\section{Screening}

Number of records screened after duplicate removed

$\mathrm{n}: 45$

Screening based on the abstract of the article

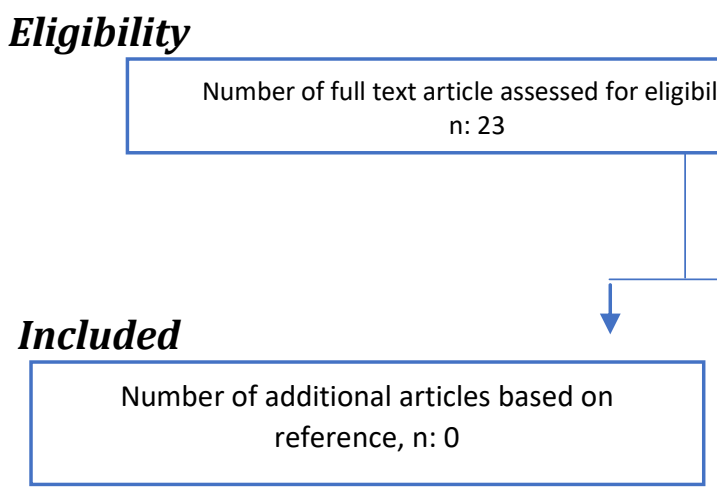

Full Article exclude based on assessment namely:

-Background research

- Method

-Findings

-Discussion

-Conclussion

\section{Included}

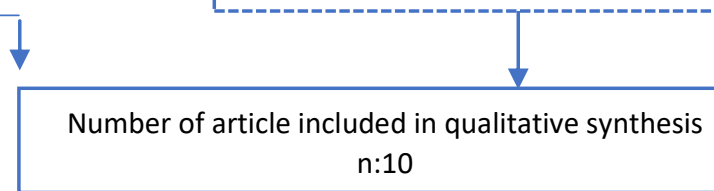

Final number of article included in synthesis $\mathrm{n}: 10$

\section{RESULT AND DISCUSSON}

Table 2, Finding

\begin{tabular}{llllll}
\hline No & $\begin{array}{c}\text { Author } \\
\text { and Year }\end{array}$ & Title & $\begin{array}{c}\text { Research } \\
\text { Design }\end{array}$ & Research Objective & Finding \\
\hline $\mathbf{1}$ & Pei-I. Chou, & Transfor & Qualitative & The use of & Through \\
& Meng- & ming & (Depth & transformationapproach & $\begin{array}{l}\text { observation, } \\
\text { interviews, and }\end{array}$ \\
& Huey Su, & teacher & Description & on CRT to facilitate the & data collection, \\
& Ya-Ting & preparati & Study) & development of & dation \\
& Wang & on for & & candidates'intrinsic & the \\
& (2018) & culturally & & motivation. The pushand & transformation of \\
& responsi & & pull of implementing & 15 candidate \\
& ve & & CRTfor candidate & teachers was \\
\hline
\end{tabular}




\begin{tabular}{|c|c|c|c|c|c|}
\hline & & $\begin{array}{l}\text { teaching } \\
\text { in } \\
\text { Taiwan }\end{array}$ & & teacher in Taiwan & $\begin{array}{l}\text { analyzed. Their } \\
\text { intrinsic } \\
\text { motivation } \\
\text { progressed from } \\
\text { "establishing } \\
\text { inclusion" to } \\
\text { "developing a } \\
\text { positive attitude," } \\
\text { "enhancing } \\
\text { meaning," and } \\
\text { finally } \\
\text { "engendering } \\
\text { competence" } \\
\text { through reflection }\end{array}$ \\
\hline 2 & $\begin{array}{l}\text { April } \\
\text { Lawrence } \\
(2017)\end{array}$ & $\begin{array}{l}\text { Toward } \\
\text { Culturall } \\
\text { y } \\
\text { Responsi } \\
\text { ve Online } \\
\text { Pedagogy } \\
: \\
\text { Practices } \\
\text { of } \\
\text { Selected } \\
\text { Secondar } \\
\text { y Online } \\
\text { Teachers }\end{array}$ & $\begin{array}{l}\text { Grounded } \\
\text { Theory } \\
\text { Research }\end{array}$ & $\begin{array}{l}\text { Exploring the teacher } \\
\text { patterns ofculturally } \\
\text { responsive } \\
\text { onlineinstruction to } \\
\text { build a groundedlocal } \\
\text { theory of } \\
\text { culturallyresponsive } \\
\text { online pedagogy(CROP) }\end{array}$ & $\begin{array}{l}\text { The results } \\
\text { indicated that the } \\
\text { teachers engaged } \\
\text { in frequent and } \\
\text { ongoing dialogue } \\
\text { with their } \\
\text { students. The } \\
\text { teachers used } \\
\text { multiple strategies } \\
\text { to get to know } \\
\text { their students, to } \\
\text { build class } \\
\text { community, to } \\
\text { adapt instruction } \\
\text { to students' } \\
\text { learning needs } \\
\text { and preferences, } \\
\text { and to make } \\
\text { learning relevant. } \\
\text { Teachers also } \\
\text { discussed } \\
\text { contextual factors } \\
\text { (e.g., program } \\
\text { structure and } \\
\text { student } \\
\text { enrollment) that } \\
\text { impacted their } \\
\text { practice.(Lawrenc } \\
\text { e, 2017) }\end{array}$ \\
\hline 3 & $\begin{array}{l}\text { Balamurali } \\
\text { thara } \\
\text { Balakrishn } \\
\text { an,HorBen } \\
\text { g Chong, } \\
\text { Muhamad } \\
\text { Zaffwan } \\
\text { Idris, } \\
\end{array}$ & $\begin{array}{l}\text { Improvin } \\
\mathrm{g} \\
\text { theEnglis } \\
\mathrm{h} \\
\text { literacys } \\
\text { kills of } \\
\text { Malaysia } \\
\text { ndyslexic }\end{array}$ & $\begin{array}{l}\text { Quasi } \\
\text { experiment }\end{array}$ & $\begin{array}{l}\text { This study examined } \\
\text { anewly developed, } \\
\text { culturallyresponsive } \\
\text { mobilemultimedia tool } \\
\text { for learningEnglish } \\
\text { among } \\
\text { dyslexicchildren.The tool } \\
\text { is acombination of both }\end{array}$ & $\begin{array}{l}\text { After doing teh } \\
\text { evaluation,The } \\
\text { study found that } \\
\text { the developed } \\
\text { multimedia tool } \\
\text { improved both } \\
\text { writing and } \\
\text { reading capability }\end{array}$ \\
\hline
\end{tabular}




\begin{tabular}{|c|c|c|c|c|c|}
\hline & $\begin{array}{l}\text { Ahmad } \\
\text { Nizam } \\
\text { Othman, } \\
\text { Muhamma } \\
\text { d } \\
\text { FadhilWon } \\
\text { g, } \\
\text { Mohamed } \\
\text { Nor } \\
\text { AzhariAzm } \\
\text { an (2015) }\end{array}$ & $\begin{array}{l}\text { children: } \\
\text { The case } \\
\text { ofcultural } \\
\text { ly } \\
\text { responsi } \\
\text { vemobile } \\
\text { multimed } \\
\text { iatool }\end{array}$ & & $\begin{array}{l}\text { cultural and linguistic } \\
\text { features in the context of } \\
\text { learning English among } \\
\text { Malaysian dyslexic } \\
\text { children who had } \\
\text { different phonological } \\
\text { process in utilizing audio } \\
\text { capturing tool which } \\
\text { affects their literacy } \\
\text { skills development }\end{array}$ & $\begin{array}{l}\text { of the participants } \\
\text { compared to } \\
\text { traditional } \\
\text { training method. } \\
\text { This provides } \\
\text { evidence that the } \\
\text { newly developed } \\
\text { culturally } \\
\text { responsive } \\
\text { multimedia tool } \\
\text { could } \\
\text { substantially } \\
\text { benefit dyslexic } \\
\text { Malaysian } \\
\text { Englishlearners as } \\
\text { well as language } \\
\text { instructors who } \\
\text { train dyslexic } \\
\text { students to } \\
\text { acquire literacy } \\
\text { skills and attain } \\
\text { their better } \\
\text { learning } \\
\text { capability. }\end{array}$ \\
\hline 4 & $\begin{array}{l}\text { Ega } \\
\text { Gradini \& } \\
\text { Firmansya } \\
\text { h (2020) }\end{array}$ & $\begin{array}{l}\text { Measurin } \\
\text { g } \\
\text { Students' } \\
\text { Mathema } \\
\text { tical } \\
\text { Literacy } \\
\text { in } \\
\text { Culturall } \\
\text { y } \\
\text { Responsi } \\
\text { ve } \\
\text { Mathema } \\
\text { tics } \\
\text { Classroo } \\
\text { m }\end{array}$ & $\begin{array}{l}\text { Experiment } \\
\text { al Research }\end{array}$ & $\begin{array}{l}\text { This paper aims to } \\
\text { discuss students' } \\
\text { mathematics literacy in } \\
\text { culturally responsive } \\
\text { mathematics classroom. } \\
\text { Students were taught by } \\
\text { culturally responsive } \\
\text { mathematics material } \\
\text { and examined with a } \\
\text { series of test in order to } \\
\text { measure their } \\
\text { mathematicsliteracy } \\
\text { level. }\end{array}$ & $\begin{array}{l}\text { This study found } \\
\text { that the level of } \\
\text { students' } \\
\text { mathematical } \\
\text { literacy taught by } \\
\text { culturally } \\
\text { responsive } \\
\text { mathematics } \\
\text { different } \\
\text { significantly from } \\
\text { students who } \\
\text { were not. } \\
\text { Descriptively, the } \\
\text { average level of } \\
\text { students in } \\
\text { culturally } \\
\text { responsive } \\
\text { mathematics class } \\
\text { is higher than } \\
\text { students who are } \\
\text { not. }\end{array}$ \\
\hline 5 & $\begin{array}{l}\text { Laela } \\
\text { Hikmah } \\
\text { Nurbatra } \\
(2018)\end{array}$ & $\begin{array}{l}\text { Learning } \\
\text { In } \\
\text { Diversity: } \\
\text { Indonesi } \\
\text { an } \\
\text { Multicult } \\
\end{array}$ & Case Study & $\begin{array}{l}\text { The study aims } \\
\text { ininvestigating } \\
\text { studentperspectives in } \\
\text { amulticultural } \\
\text { classroomabout } \\
\text { multiculturaleducation.I }\end{array}$ & $\begin{array}{l}\text { The results } \\
\text { indicated that the } \\
\text { challenges in the } \\
\text { implementation of } \\
\text { multicultural } \\
\text { pedagogy cover }\end{array}$ \\
\hline
\end{tabular}




\begin{tabular}{|c|c|c|c|c|c|}
\hline & & $\begin{array}{l}\text { ural } \\
\text { Classroo } \\
\mathrm{m}\end{array}$ & & $\begin{array}{l}\mathrm{n} \text { detail, the paper } \\
\text { highlights the challenges } \\
\text { faced by the students in } \\
\text { multicultural classroom } \\
\text { in the perspective of } \\
\text { Indonesian and Chinese } \\
\text { students. }\end{array}$ & $\begin{array}{l}\text { four areas such as } \\
\text { language barrier, } \\
\text { cultural } \\
\text { differences, } \\
\text { familiarity to } \\
\text { certain topic, and } \\
\text { teaching practice. }\end{array}$ \\
\hline 6 & $\begin{array}{l}\text { Noraini } \\
\text { Omar,Latif } \\
\text { ah Abdul } \\
\text { Majid, } \\
\text { Mohd } \\
\text { AderiCheN } \\
\text { oh, } \\
\text { MohdIsaH } \\
\text { amzah }\end{array}$ & $\begin{array}{l}\text { Multi- } \\
\text { Cultural } \\
\text { Perspecti } \\
\text { ve In The } \\
\text { Teaching } \\
\text { Of } \\
\text { Islamic } \\
\text { Educatio } \\
\text { n In } \\
\text { Malaysia }\end{array}$ & Case Study & $\begin{array}{l}\text { This study aims to } \\
\text { explore teachers' } \\
\text { understanding of } \\
\text { cultural diversity among } \\
\text { the students. }\end{array}$ & $\begin{array}{l}\text { The study found } \\
\text { that teachers have } \\
\text { given four main } \\
\text { themes in } \\
\text { discussing the } \\
\text { concept of cultural } \\
\text { diversity in the } \\
\text { teaching of Islam } \\
\text { that encompasses } \\
\text { various religious } \\
\text { practices, various } \\
\text { values, diversity of } \\
\text { peoples and } \\
\text { nations and } \\
\text { languages. } \\
\text { Understanding of } \\
\text { different cultures } \\
\text { help Islamic } \\
\text { Education } \\
\text { teachers to } \\
\text { understand the } \\
\text { way people live } \\
\text { and everyday } \\
\text { practice of student } \\
\text { life, thus can } \\
\text { provide an } \\
\text { equitable } \\
\text { education to meet } \\
\text { the needs of } \\
\text { different } \\
\text { students.(Noraini } \\
\text { Omar et al., 2016) }\end{array}$ \\
\hline 7 & $\begin{array}{l}\text { Christy M. } \\
\text { Rhodes } \\
2017\end{array}$ & $\begin{array}{l}\text { A } \\
\text { Validatio } \\
\mathrm{n} \text { Study } \\
\text { of the } \\
\text { Culturall } \\
\mathrm{y} \\
\text { Responsi } \\
\text { ve } \\
\text { Teaching } \\
\text { Survey }\end{array}$ & $\begin{array}{l}\text { Quantitative } \\
\text { with survey } \\
\text { methodolog } \\
\text { y }\end{array}$ & $\begin{array}{l}\text { This study aims to } \\
\text { explain the } \\
\text { implementation of CRT } \\
\text { and determined the } \\
\text { psychometric nature of } \\
\text { the CRTS 'teaching } \\
\text { studies }\end{array}$ & $\begin{array}{l}\text { CTRS shows a } \\
\text { positive } \\
\text { correlation with } \\
\text { understanding } \\
\text { and proficiency } \\
\text { teaching different } \\
\text { cultures and CTRS } \\
\text { provides useful } \\
\text { tools for a } \\
\text { practical } \\
\text { examination. }\end{array}$ \\
\hline 8 & Mohd Ali & Assessing & Quantitative & For measuring the & ICTE-Q is a valid \\
\hline
\end{tabular}




\begin{tabular}{|c|c|c|c|c|c|}
\hline & $\begin{array}{l}\text { Samsudin, } \\
\text { Anna } \\
\text { Christina } \\
\text { Abdullah, } \\
\text { Melissa Ng } \\
\text { Lee Yen, } \\
\text { Abdullah } \\
\text { and } \\
\text { Najeemah } \\
\text { MohdYuso } \\
\text { f } 2019\end{array}$ & $\begin{array}{l}\text { the } \\
\text { Psychom } \\
\text { etric } \\
\text { Propertie } \\
\mathrm{s} \text { of the } \\
\text { Intercult } \\
\text { ural } \\
\text { Compete } \\
\text { nce in } \\
\text { Teacher } \\
\text { Educatio } \\
\text { n } \\
\text { Question } \\
\text { naire } \\
\text { (ICTE-Q) }\end{array}$ & Model Rasch & $\begin{array}{l}\text { teacher's multicultural } \\
\text { competence and } \\
\text { consciousness }\end{array}$ & $\begin{array}{l}\text { instrument } \\
\text { measuring the } \\
\text { competency } \\
\text { across the } \\
\text { teacher's } \\
\text { educational } \\
\text { program. }\end{array}$ \\
\hline 9 & $\begin{array}{l}\text { B. } \\
\text { Campbell,2 } \\
018\end{array}$ & $\begin{array}{l}\text { Switchin } \\
\text { g } \\
\text { Colours: } \\
\text { Becomin } \\
\text { g A } \\
\text { Culturall } \\
\text { y } \\
\text { Responsi } \\
\text { ve } \\
\text { Teacher } \\
\text { Educator }\end{array}$ & $\begin{array}{l}\text { Qualitative: } \\
\text { Narrative } \\
\text { self } \\
\text { study\&Narr } \\
\text { ative } \\
\text { Inquiry }\end{array}$ & $\begin{array}{l}\text { The researcher wants to } \\
\text { explore how the teacher } \\
\text { sought to bridge the gap } \\
\text { between herself, her } \\
\text { participant students and } \\
\text { a Victorian novel as her } \\
\text { Endeavored to become } \\
\text { more purposeful in her } \\
\text { pedagogy. }\end{array}$ & $\begin{array}{l}\text { The cultural } \\
\text { responsive help } \\
\text { the pre-teacher to } \\
\text { more aware of } \\
\text { individuals'. } \\
\text { The cultural } \\
\text { responsive make } \\
\text { the pre-teacher } \\
\text { learnt the } \\
\text { construct } \\
\text { knowledge in } \\
\text { jointly with the } \\
\text { students } \\
\text { The pre-teacher } \\
\text { let the students } \\
\text { engage in the } \\
\text { story by playing } \\
\text { the role directly in } \\
\text { the story. } \\
\text { CRT really } \\
\text { matches with the } \\
\text { students need. }\end{array}$ \\
\hline 10 & $\begin{array}{l}\text { Roselle } \\
\text { S. Maestro, } \\
\text { Marian Ra } \\
\text { mos- } \\
\text { Eclevia } \\
\text {,Carlos } \\
\text { L. Eclevia } \\
\text { Jr. \& John } \\
\text { Christophe } \\
\text { rson } \\
\text { L.T. Fredel } \\
\text { uces, } 2018\end{array}$ & $\begin{array}{l}\text { Teaching } \\
\text { Diversity, } \\
\text { Becomin } \\
\text { g } \\
\text { Inclusive: } \\
\text { Perspecti } \\
\text { ves and } \\
\text { Possibilit } \\
\text { ies in } \\
\text { ASEAN } \\
\text { Library } \\
\text { and } \\
\text { Informati } \\
\text { on }\end{array}$ & $\begin{array}{l}\text { Mix method } \\
\text { of } \\
\text { Qualitative } \\
\text { survey and } \\
\text { content } \\
\text { Analysis }\end{array}$ & $\begin{array}{l}\text { The researcher wants to } \\
\text { investigate how courses } \\
\text { and topics about } \\
\text { diversity and inclusion } \\
\text { are being integrated into } \\
\text { the Library and } \\
\text { Information Science } \\
\text { (LIS) curriculum among } \\
\text { selected library schools } \\
\text { in the member countries } \\
\text { of the Association of } \\
\text { Southeast Asian Nations } \\
\text { (ASEAN). } \\
\text { The researcher wants to }\end{array}$ & $\begin{array}{l}\text { The cultural } \\
\text { competence in } \\
\text { ASEAN is } \\
\text { beneficial for the } \\
\text { library staff to } \\
\text { deal with a } \\
\text { diverse } \\
\text { community, from } \\
\text { different race, } \\
\text { gender, religion, } \\
\text { age and disability } \\
\text { of the students. } \\
\text { Cultural } \\
\text { competence also }\end{array}$ \\
\hline
\end{tabular}




\begin{tabular}{lll}
\hline $\begin{array}{l}\text { Science } \\
\text { Schools }\end{array}$ & $\begin{array}{l}\text { examine the } \\
\text { characteristics and roles } \\
\text { of culturally responsive }\end{array}$ & $\begin{array}{l}\text { helps the librarian to } \\
\text { understand and } \\
\text { treat the students } \\
\text { fiS faculty in teaching }\end{array}$ \\
& & country. \\
& & (Maestro et al., \\
& & 2018) \\
\hline
\end{tabular}

From the data acquired after screening by utilizing PRISMA Protocol, out of 45 journal articles there are 10 journal articles which answered the background of this study. As culturally responsive teaching (CRT) only considered as teaching that only focus on culture, ethnic and race possessed by the students, these 10 journals break those concepts. CRT is not that narrow matter but it is broader than what some preview studies and experts defined. There are two main points are appointed as the importance of CRT; the CRT misconception and CRT as the tool of bridging between teacher and student to understand diversities in teaching and learning process.

\section{Misconception of Culturally Responsive Teaching (CRT)}

A study conducted by Christy M. Rhodes (2017) found that there was positive correlation of teacher in conducting Psychometric culture evaluation to students in the classroom that assist teachers to develop the students' character, understanding and knowledge in learning multicultural comprehension process. This indicates that CRT could be the intervention for the teacher to consider the way to evaluate students' understanding and knowledge regarding the culture of certain community or place. Additionally, Based on a study committed by (Chou et al. 2018) it found that a teacher does not only apply CRT method as inclusive classroom strategy to encourage the students to study together but also teacher has a positive attitude toward the students in the classroom. Therefore, when facing the multicultural and difference, the teacher becomes more respectful to the heterogeneity so do the students. This is occurred because there is an opportunity to reflect the teaching and learning activities in which the teachers required to understand their class deeper. Moreover, April Lawrence (2017) explored teachers' arrangement in implementing CRT by online indicated that the teacher engaged in frequent and ongoing dialogue with their students. The teachers used multiple strategies to get to know their students, to build class community, to adapt instruction to students learning needs and preferences, and to make learning relevant. Teachers also discussed contextual factor (e. g program structure and students enrolment) impacting their practices. Thus, CRT focuses on convincing the relevancy of knowledge and learning style gained by the students in order to contribute meaningful teaching and learning to face the real-life condition.

Furthermore, Study conducted by Nurbatra (2018) asserted that CRT is not only about how the teachers interact with the multicultural students but also about how teachers are trained to teach the students to respect the diversity in a classroom such as talking in gesture, try to speak in English and conduct more group discussions to maximize the interaction between Indonesian and Chinese students rather than homogenous interaction. In this case CRT has a role to encourage both teacher and students to learn more and possessed high tolerance toward the heterogeneity in the classroom. CRT method is also utilized in assisting both teachers and students to understand the concept of mathematic formula.

This is shown in the study committed by Gradini (2019) stated that the teachers pay attention on guiding students, providing meaningful negotiators, and facilitating 
students in exploring, analyzing, and summarizing. The teacher must not be an authoritarian and the only source of information for students. Moreover, the teacher must be able to design an active, creative, and interesting learning process. Working more in group with multicultural members, teaching the value of democracy and attitude and giving a complex learning task required a number of members in group to participate are several recommended way to apply CRT in mathematic class.

Last but not least, CRT is utilized as one of the pivotal element in designing a tool to learn language for dyslexic children (Balakrishnan et al. 2017). The concept of this tool is to be able to facilitate to dyslexic student to be able to get equal opportunity as the normal student acquired in learning English language. This concept in line with the statement of Khadir Rajagopal (2011) that teaching should be able to touch every characteristic of student, it is not only applicable for particulars group but it also should be acceptable for all groups in a class.

\section{CRT as the Bridge}

The next concept is CRT as the tool of bridging between a teacher and students. A study conducted by Samsudin et al. (2019) ICTI-Q can measure a teacher ability and competence in comprehending teaching and learning process by CRT method. CRT becomes the bridge between teachers and students through students' role involving in a novel character. When the teachers deliver the story, students will feel involved in the novel story (Campbell 2018) In ASEAN countries CRT is required for the library staff to enable them understanding the diversity among international and local students. CRT will make the work for the library staff easier to understand cultural diversities of the students. Thus, CRT indeed does not only result limited in the classroom situation, but also it will benefit the students in the future career. Additionally study about perception of Islamic teachers in teaching their students with different religion, race and culture indicated that the way to respect the diversity is by celebrating the diversity, this is also in line with KPM (Ministry of Malaysian Education) that recommends school to celebrate diversity as a proof to respect them.

A teacher has a role to understand students' various culture, background and personality, the most importantly, the existence of a teacher is not simply to make difference in students score, beyond that all, a teacher should focus on getting the students to care about learning (Rajagopal, 2011). To make it real, CRT approach can be a trigger to reach that goal. This role of bridging is in line with all studies synthesized in this systematic review. Being able to adapt teaching method to be accepted by the students, being able to respect others' diversity and way of teaching and being able to creatively create and invent teaching tool to provide equality are all the outcomes of CRT that contribute positively to all elements involved in teaching and learning process. Last but not least, in applying CRT a teacher does not necessarily to fake or totally lost their comfort way in teaching in order to meet the goal of equality. It might affect their performance and the worst might cause the loss of teaching and learning goal. A study conducted by Balakrishnan et al. (2017), the establishment of English language learning tool for dyslexic student is also to assist the teacher students with special need. Thus, it will affect positively both teachers and students.

Thus, it is hoped that this study enables the teachers refresh their perspective in understanding the concept of CRT based on the journals synthesized above that CRT is not only used to handle the multicultural students but also the variation of the class for instance the way inclusive class conducted. Moreover, CRT is also utilized to overcome higher power distance between students and teachers in ASEAN countries. 


\section{CONCLUSION}

The teacher does not only apply CRT method as inclusive classroom strategy to encourage the students to study together but also teacher has a positive attitude toward the students in the classroom. Furthermore, CRT is not only about how the teachers interact with the multicultural students but also about how teachers are trained to teach the students to respect the diversity in a classroom such as talking in gesture, decrease the high power distance between the teachers and students, conduct more group discussions to maximize the interaction between students rather than homogenous interaction. In this case CRT has a role to encourage both teacher and students to learn more and possessed high tolerance toward the heterogeneity in the classroom. Thus, CRT brought the positive affects to both teachers and students.

\section{ACKNOWLEDGEMENT}

This study was undertaken as final assignment accomplishment of one of mandatory courses in Curriculum and Pedagogy major of Faculty of education, The National University of Malaysia. Special gratitude is addressed to Dr. Nurfaradilla Binti Muhammad Nasri and Dr. Isa Bin Hamzah as the lecturers and assessors of this study. Unforgettable thanks is granted to all writes of this study who have given their big effort to the accomplishment of this study.

\section{AUTHOR CONTRIBUTION STATEMENT}

This study was conducted by four authors from the same university and major, Curriculum and Pedagogy, Faculty of Education, The National University of Malaysia. This study is intended to be published as the contribution on education field Culturally Responsive Curriculum (CRT) and references for in depth study regarding this study in the future for any institutions.

\section{REFERENCES}

Albantani, A. M., \& Madkur, A. (2018). Think globally, act locally: the strategy of incorporating local wisdom in foreign language teaching in indonesia. International Journal of Applied Linguistics and English Literature, 7(2), 1-8. http://dx.doi.org/10.7575/aiac.ijalel.v.7n.2p.1

Balakrishnan, B., Chong, H. B., Idris, M. Z., Othman, A. N., Wong, M. F., \& Azman, M. N. A. (2017). Improving the English literacy skills of Malaysian dyslexic children: The case of culturally responsive mobile multimedia tool.Geografia-Malaysian Journal of Society and Space, 11(13). Google Scholar

Bity Salwana Alias, Zaida Nor Zainudin, Nurfaradilla Mohamad Nasri, (2018). Curriculum Management Competency of Malaysia's Principal. International Journal of Academic Research in Business \& Social Sciences. 8(10): 1101-1107. Google Scholar

Bonner, P. J., Warren, S. R., \& Jiang, Y. H. (2018). Voices from urban classrooms: Teachers' perceptions on instructing diverse students and using culturally responsive teaching. $\begin{array}{llll}\text { Education } \quad \text { and } & \text { 60 }\end{array}$ https://doi.org/10.1177/0013124517713820

Campbell, B. (2018). Switching colours: Becoming a culturally responsive teacher educator. South African Journal of Higher Education, 32(6). https://doi.org/10.20853/32-6-2938

Chou, P. I., Su, M. H., \& Wang, Y. T. (2018). Transforming teacher preparation for culturally responsive teaching in Taiwan. Teaching and Teacher Education, 75, 116-127. https://doi.org/10.1016/j.tate.2018.06.013

Donna M. Sobel, Sheryl V. Taylor. (2011). Culturally Responsive Pedagogy: Teaching Like Our Students' Live Matter. Bingley: Emerald Books. Google Scholar

Gay G. (2000). Culturally Responsive Teaching: Theory, Research, Practice. Multicultural, 
Education Series. (A.B, James, Ed.) New York: Teacher College Press.

Gay G. (2012). Culturally Responsive Teaching. Culturally Responsive Curriculum, Assesment, and Instruction [Seminar]. University of Wangshiton, September, Session 9 Spring 2012.

Gradini, E., \& Firmansyah, F. (2019). Measuring Students' Mathematical Literacy in Culturally Responsive Mathematics Classroom. Al-Ta lim Journal,26(3), 233-242. http://dx.doi.org/10.15548/jt.v26i3.551

Hernandez, C. M., Morales, A. R., \& Shroyer, M. G. (2013). The development of a model of culturally responsive science and mathematics teaching. Cultural Studies of Science Education, 8(4), 803-820. https://doi.org/10.1007/s11422-013-9544-1

Heto, P. P. K., Odari, M. H., \& Sunu, W. K. (2020). Different Schools, Different Cultures. Handbook on Promoting Social Justice in Education, 583-608.

Khalifa, M. A., Gooden, M. A., \& Davis, J. E. (2016). Culturally responsive school leadership: A synthesis of the literature. Review of Educational Research, 86(4), 1272-1311. https://doi.org/10.3102\%2F0034654316630383

Kusumaningputri, R., \& Widodo, H. P. (2018). Promoting Indonesian university students' critical intercultural awareness in tertiary EAL classrooms: The use of digital photograph-mediated intercultural tasks. System, 72, 49-61. https://doi.org/10.1016/j.system.2017.10.003

Lawrence, A. (2017). W \& M ScholarWorks Toward Culturally Responsive Online Pedagogy: Practices of Selected Secondary Online Teachers. https://doi.org/10.21220/W4MD4K

Latrous, W. O., \& Khadraoui, M. (2020). Cultural Challenges of E-Learning Experiences: An Exploratory Research. International Journal of E-Services and Mobile Applications (IJESMA), 12(3), 18-37. DOI: 10.4018/IJESMA.2020070102

Lawrence, A. (2017). Toward Culturally Responsive Online Pedagogy: Practices of Selected Secondary Online Teachers. http://dx.doi.org/doi:10.21220/W4MD4K

M. Rhodes, C. (2017). A Validation Study of the Culturally Responsive Teaching Survey. Universal Journal of Educational Research, 5(1), 45-53. https://doi.org/10.13189/ujer.2017.050106

Maestro, R. S., Ramos-Eclevia, M., Eclevia, C. L., \& Fredeluces, J. C. L. T. (2018). Teaching Diversity, Becoming Inclusive: Perspectives and Possibilities in ASEAN Library and Information Science Schools. Journal of the Australian Library and Information Association, 67(2), 96-115. https://doi.org/10.1080/24750158.2018.1467142

Noraini Omar, Latifah Abdul Majid, Mohd Aderi Che Noh, \& Mohd Isa Hamzah. (2016). Multi-Cultural Perspective in the Teaching of Islamic Education in Malaysia. Tinta Artikulasi Membina Ummah, 2(1), 67-79.

Nurbatra, L. H. (2018). Learning in Diversity: Indonesian Multicultural Classroom. 231238

Parlindungan, F., Rifai, I., \& Safriani, A. (2018). The representation of Indonesian cultural diversity in middle school English textbooks. Indonesian Journal of Applied Linguistics, 8(2), 289-302. https://doi.org/10.17509/ijal.v8i2.13276

Porto, M. (2019). Affordances, complexities, and challenges of intercultural citizenship for foreign language teachers. Foreign Language Annals, 52(1), 141-164. https://doi.org/10.1111/flan.12375

Rajagopal, K. (2011.). Create Success! (Unlocking the potential of urban Students). ASCD, Alexandria, Virginia USA.

Raymond, C. Y., \& Choon, T. (2017). Understanding Asian students learning styles, cultural influence and learning strategies. Journal of Education \& Social Policy, 7(1), 194-210.

Rychly, L., \& Graves, E. (2012). Teacher characteristics for culturally responsive pedagogy. Multicultural $\quad$ Perspectives, $14(1), \quad 44-49$. https://doi.org/10.1080/15210960.2012.646853

Samsudin, M. A., Abdullah, A. C., Abdullah, M. N. L. Y., \& Yusof, N. M. (2019). Assessing the 
psychometric properties of the intercultural competence in teacher education questionnaire (ICTE-Q). Pertanika Journal of Social Sciences and Humanities, 27(3), $1691-1707$

Suhono, S. (2019). Providing explicit strategy instruction to enhance students'reading comprehension at english for islamic studies class. jurnal smart, 5(2), 81-93. Google Scholar

Wang, M. T., Degol, J. L., \& Henry, D. A. (2019). An integrative development-insociocultural-context model for children's engagement in learning. American Psychologist, 74(9), 1086. https://doi.org/10.1037/amp0000522

\section{Copyright Holder :}

(C) Trisnawati, S., Al-Kautsar, K., Hamdiah, H., \& Dewi, S., (2020).

\section{First Publication Right :}

(C) Anglophile Journal

This article is under:

CC BY SA 